\title{
$\mathrm{V}, \mathrm{Nb}$ 첨가 고강도 대형 $\mathrm{H}$ 형강의 부위별 미세조직과 경도 분포
}

\author{
하양수 · 정재길 - 이영국 ${ }^{\dagger}$ \\ 연세대학교 공과대학 신소재공학과
}

\section{Microstructures and Hardness Distributions of a Large-sized High Strength H-sectional Steel with Both $\mathrm{V}$ and $\mathrm{Nb}$}

\author{
Yangsoo Ha, Jae-Gil Jung, Young-Kook Lee \\ Department of Materials Science and Engineering, Yonsei University, Seoul 120-749, Korea
}

\begin{abstract}
The microstructures and hardness distributions of a large-sized high strength $\mathrm{H}$-sectional steel with both $\mathrm{V}$ and $\mathrm{Nb}$ were systematically examined. The outer surface of the flange part was composed of martensite and bainite due to faster cooling, and had a high hardness value of approximately $310 \mathrm{Hv}$. However, the amounts of ferrite and pearlite increased and the hardness decreased with increasing the distance from the outer surface at the flange part, except the inner surface. High hardness value of about $290 \mathrm{Hv}$ was measured at the upper surface of the web part having martensite and bainite. The hardness drastically decreased with increasing the web thickness, and then greatly rose again at the lower surface due to bainite formation caused by fast air cooling. The hardness of the flange part was higher than that of the web part due to the larger amount of low-temperature transformed phases, except for the lower surface of the web part. Nb-rich precipitates of 30 to $50 \mathrm{~nm}$ and V-rich precipitates less than $20 \mathrm{~nm}$ were observed at both flange and web parts. However, the particle size was smaller at the flange part than the web part, resulting in the higher strength of the flange part.
\end{abstract}

(Received January 3, 2013; Revised February 20, 2013; Accepted March 8, 2013)

Key words : Microalloyed steel, Sectional steel, Microstructure, Precipitates, Hardness

\section{1. 서 론}

최근 초고층 빌딩, 장대 교량, 대공간 구조물 등 건축 구조물의 형태가 거대화되면서 강구조물에 사용 되는 대형 철강 소재의 성능 개선에 대한 요구가 증대되고 있다. 그 중 $\mathrm{H}$ 형강은 강구조물에 쓰이는 대표적인 철강소재로서 건축 구조물이 대형화, 장대 화 됨에 따라 높은 강도와 인성을 겸비한 대형 $\mathrm{H}$ 형강의 수요가 점차 증가하고 있다.

$\mathrm{H}$ 형강의 고강도화는 주로 $\mathrm{V}, \mathrm{Nb}, \mathrm{Ti}$ 등의 미량 합금 원소의 첨가에 의한 결정립 미세화와 탄질화물 형성에 의한 석출 강화를 통해 이루어지고 있다[14]. 즉, 미량 합금강(microalloyed steel)에 첨가된 $\mathrm{V}, \mathrm{Nb}$ 등은 열간압연과 냉각 공정 중 탄소 및 질소 와 반응하여 탄질화물 형태의 미세한 석출물을 형성 한다. 이들 탄질화물은 열간압연 중 오스테나이트의

Corresponding author. E-mail : yklee@yonsei.ac.kr Copyright (c) The Korean Society for Heat Treatment
재결정 및 결정립 성장을 억제하여 페라이트의 결정 립을 미세화시키고, 냉각 및 권취 시 미세하게 석출 하여 강의 기계적 성질을 크게 향상시키기 때문이다. 그 외에도 열간압연 온도와 압하율 제어를 통해 페 라이트의 결정립을 미세화하여 $\mathrm{H}$ 형강의 기계적 특 성을 향상시키는 연구도 이루어지고 있다[5-7].

한편, 미세한 결정립의 페라이트 조직만으로는 최 근 요구되는 고강도 대형 $\mathrm{H}$ 형강의 기계적 성질을 만족시키는데 한계가 있어, 열간압연 후 냉각수 분사 를 통한 가속냉각을 통해 저온변태조직에 의한 강화 를 이용하는 연구가 이루어지고 있다[8-10]. 그런데, 실제 조업 시 대형 $\mathrm{H}$ 형강의 전 부위를 균일하게 가속 냉각하는 것은 매우 어렵기 때문에, $\mathrm{H}$ 형강의 각 부위별, 두께별 냉각속도의 불균일이 불가피하게 발생한다. 이러한 $\mathrm{H}$ 형강 내 냉각속도의 불균일은 상변화와 석출물 분포와 같은 미세조직과 그에 따른 


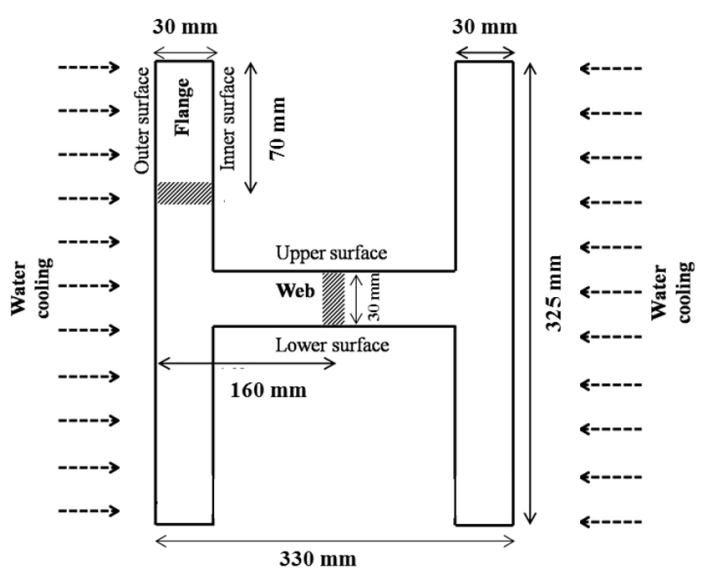

Fig. 1. Schematic illustration of the cross-sectional shape of the H-sectional steel and cooling condition. Specimens for microstructural observation and hardness tests were taken from the hatched areas of flange and web parts.

기계적 성질에 크게 영향을 주지만, 이들에 대한 연 구는 미비한 상황이다. 따라서, 본 연구에서는 $\mathrm{V}$, $\mathrm{Nb}$ 첨가 미량 합금강을 가속냉각하여 제조한 $600 \mathrm{MPa}$ 급의 인장강도를 가지는 고강도 대형 $\mathrm{H}$ 형강의 부위별 미세조직과 그에 따른 경도변화를 체 계적으로 연구하고자 하였다.

\section{2. 실험 방법}

본 연구에서 사용된 $\mathrm{V}$ 과 $\mathrm{Nb}$ 이 복합 첨가된 $\mathrm{H}$ 형강의 화학 조성은 중량비로 $\mathrm{Fe}-0.13 \mathrm{C}-1.29 \mathrm{Mn}$ $0.21 \mathrm{Si}-0.066 \mathrm{~V}-0.050 \mathrm{Nb}-0.013 \mathrm{~N}$ 이다. 상기의 $\mathrm{V}, \mathrm{Nb}$ 첨가 미량 합금강에서 석출물은 $(\mathrm{V}, \mathrm{Nb})(\mathrm{C}, \mathrm{N})$ 의 복 합 탄질화물의 형태로 석출하고, 이들 석출물의 재용 해 온도는 약 $1170^{\circ} \mathrm{C}$ 로 알려져 있다[13]. 따라서, 빔블랭크(beam blank)는 첨가 원소인 $\mathrm{V}$ 과 $\mathrm{Nb}$ 을 최 대한 고용시키기 위해 $1155 \sim 1180^{\circ} \mathrm{C}$ 로 유지된 가열 로에서 가열되었다. 가열로에서 추출된 빔블랭크는 $800^{\circ} \mathrm{C}$ 이상의 온도들에서의 다단 열간압연을 통해 $\mathrm{H}$ 형강으로 제조된 후, 플랜지(flange) 양 쪽 외부 표면부분에만 냉각수를 분사하여 가속냉각되었다. 그 림 1 에 나타낸 바와 같이, $\mathrm{H}$ 형강의 플랜지의 두께 는 $30 \mathrm{~mm}$, 높이는 $325 \mathrm{~mm}$ 이었고, 웹(web)의 두께 는 $30 \mathrm{~mm}$, 그 폭은 $330 \mathrm{~mm}$ 이었다. 본 연구에 사 용된 시편은 그림 1 에 빗금으로 표시한 바와 같이,
플랜지의 외부 표면에서부터 두께 방향을 따라, 그리 고 웹의 윗 표면에서 두께 방향을 따라 각각 채취 하였으며, 모든 시편의 크기는 약 $30 \times 30 \times 10 \mathrm{~mm}^{3}$ 이었다.

미세조직 관찰을 위해 $\mathrm{H}$ 형강의 각 부위별 시편 들을 기계연마 후 $10 \%$ 나이탈 용액으로 에칭하여 광학현미경(Olympus, $\mathrm{BX} 41 \mathrm{M})$ 을 이용하여 관찰하였 다. $\mathrm{H}$ 형강의 각 부위별 경도는 미세조직 관찰 후 비커스 경도기(Mitutoyo, 810-129K)를 이용하여 $500 \mathrm{~g}$ 의 하중으로 5 회 이상 측정하였고, 이들 측정값 의 평균값을 사용하였다.

$\mathrm{H}$ 형강 내 석출물을 관찰하기 위해 플랜지와 웹의 중심부에서 탄소 추출 복제막(carbon extraction replica)를 제작하여, 투과 전자 현미경(TEM, JEOL, $\mathrm{JEM} 2100 \mathrm{~F})$ 과 에너지 분산 분광법(EDXS, Oxford, INCA Energy)을 이용해서 석출물의 크기, 조성, 형 상, 분포 등을 조사하였다.

\section{3. 결과 및 고찰}

가속냉각으로 제조된 $\mathrm{H}$ 형강의 플랜지와 윕부분을 그림 1 에 나타낸 빗금 부분에서 각각 채취하여 상온 에서 측정한 기계적 성질을 표 1 에 나타내었다[10]. 플랜지와 웹의 항복강도는 각각 $585 \mathrm{MPa}$ 와 443 $\mathrm{MPa}$ 이고, 인장강도는 각각 $699 \mathrm{MPa}$ 와 $577 \mathrm{MPa}$ 이 었다. 플랜지는 웹보다 높은 항복강도와 인장강도를 나타내었으나, 연신율은 플랜지와 웹 모두 약 $20 \%$ 로 비슷한 수준이었다. 반면, 샤르피 흡수에너지는 플랜지가 웹보다 2 배 이상 높음을 알 수 있다. 이와 같이 $\mathrm{H}$ 형강의 부위별로 기계적 성질의 차이가 나 타나는 원인을 알아보기 위해 $\mathrm{H}$ 형강의 각 부위별, 두께별 미세조직을 관찰하고 경도를 측정하였다.

그림 2 는 플랜지의 외부 표면에서부터 두께에 따 른 미세조직의 변화를 보여준다. 플랜지의 외부 표면 (그림 2(a))은 직접적인 물 분사에 의해 냉각속도가 빠르기 때문에 저온 변태 상들인 마르텐사이트와 베 이나이트의 혼합조직이 관찰되는 반면, 두께 방향으 로 $6 \mathrm{~mm}$ 지점(그림 2(b))부터는 냉각 속도가 느려 짐에 따라 마르텐사이트, 베이나이트 외에 페라이트 와 펄라이트도 소량 관찰되었다. 약 $7 \mathrm{~mm}$ 지점부터 는 마르텐사이트와 베이나이트가 거의 관찰되지 않 
Table 1. Tensile properties and toughness of flange and web parts of $\mathrm{H}$-sectional steel used in the present study[10].

\begin{tabular}{ccccc}
\hline Part & Yield strength $(\mathrm{MPa})$ & Tensile strength $(\mathrm{MPa})$ & Elongation $(\%)$ & Charpy absorbed energy at $0{ }^{\circ} \mathrm{C}(\mathrm{J})$ \\
\hline Flange & 585 & 699 & 20 & 67 \\
\hline Web & 443 & 577 & 19.4 & 31 \\
\hline
\end{tabular}

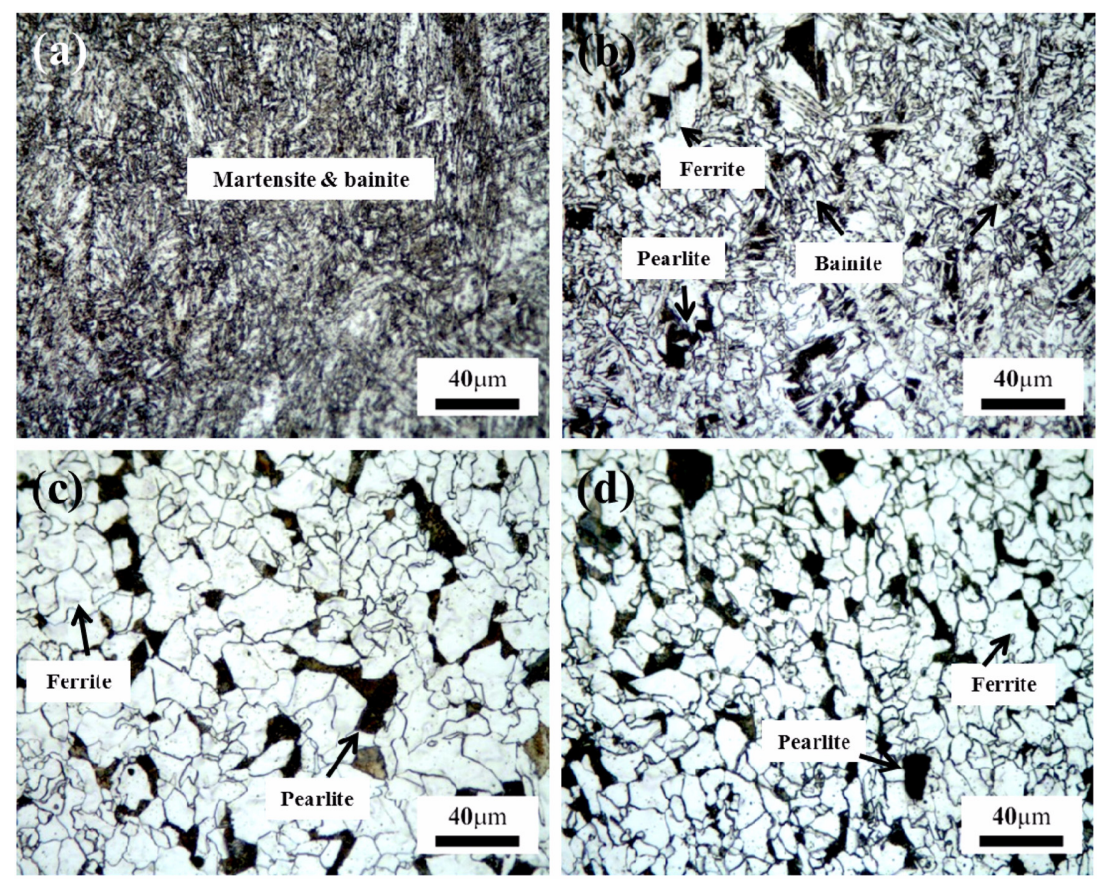

Fig. 2. Optical micrographs taken at various locations of the flange part. (a) outer surface, (b) $6 \mathrm{~mm}$ from the outer surface, (c) $15 \mathrm{~mm}$ from the outer surface, and (d) inner surface.

고, 페라이트와 펄라이트의 혼합 조직이 관찰되었다 (그림 2(c), (d)). 플랜지의 중심부(그림 2(c))에서 내 부 표면(그림 $2(\mathrm{~d})$ )으로 갈수록 펄라이트 분율은 $15 \%$ 에서 $13 \%$ 로 소폭 감소하였고, 페라이트 결정립 크기는 $14 \mu \mathrm{m}$ 에서 $10 \mu \mathrm{m}$ 로 감소하였다. 이는 가속 냉각 시 플랜지의 내부 표면으로 흘러내린 냉각수에 의해 내부 표면이 플랜지 중심부보다 더 빠르게 냉 각되었기 때문인 것으로 생각된다.

그림 3은 플랜지의 외부표면에서부터 두께방향으로 의 거리에 따른 경도 변화를 보여준다. 미세조직 변 화를 통해 예측할 수 있듯이, 마르텐사이트와 베이나 이트로 구성된 외부 표면에서는 $300 \mathrm{Hv}$ 이상의 높 은 경도를 보이는 반면, 플랜지의 외부 표면에서부터 두께방향으로의 거리가 증가함에 따라 약 $7 \mathrm{~mm}$ 지 점까지 경도 값은 급격히 감소함을 알 수 있다. 이 는 플랜지의 두께가 증가함에 따라 느려진 냉각속도

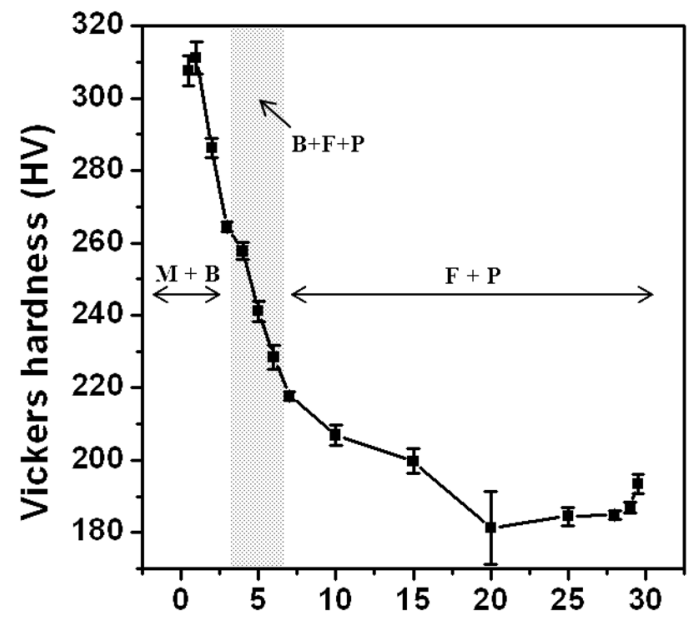

\section{Distance from outer surface $(\mathrm{mm})$}

Fig. 3. Variation in hardness with the distance from the outer surface of the flange part. $\mathrm{M}, \mathrm{B}, \mathrm{F}$, and $\mathrm{P}$ indicate martensite, bainite, ferrite, and pearlite, respectively. 


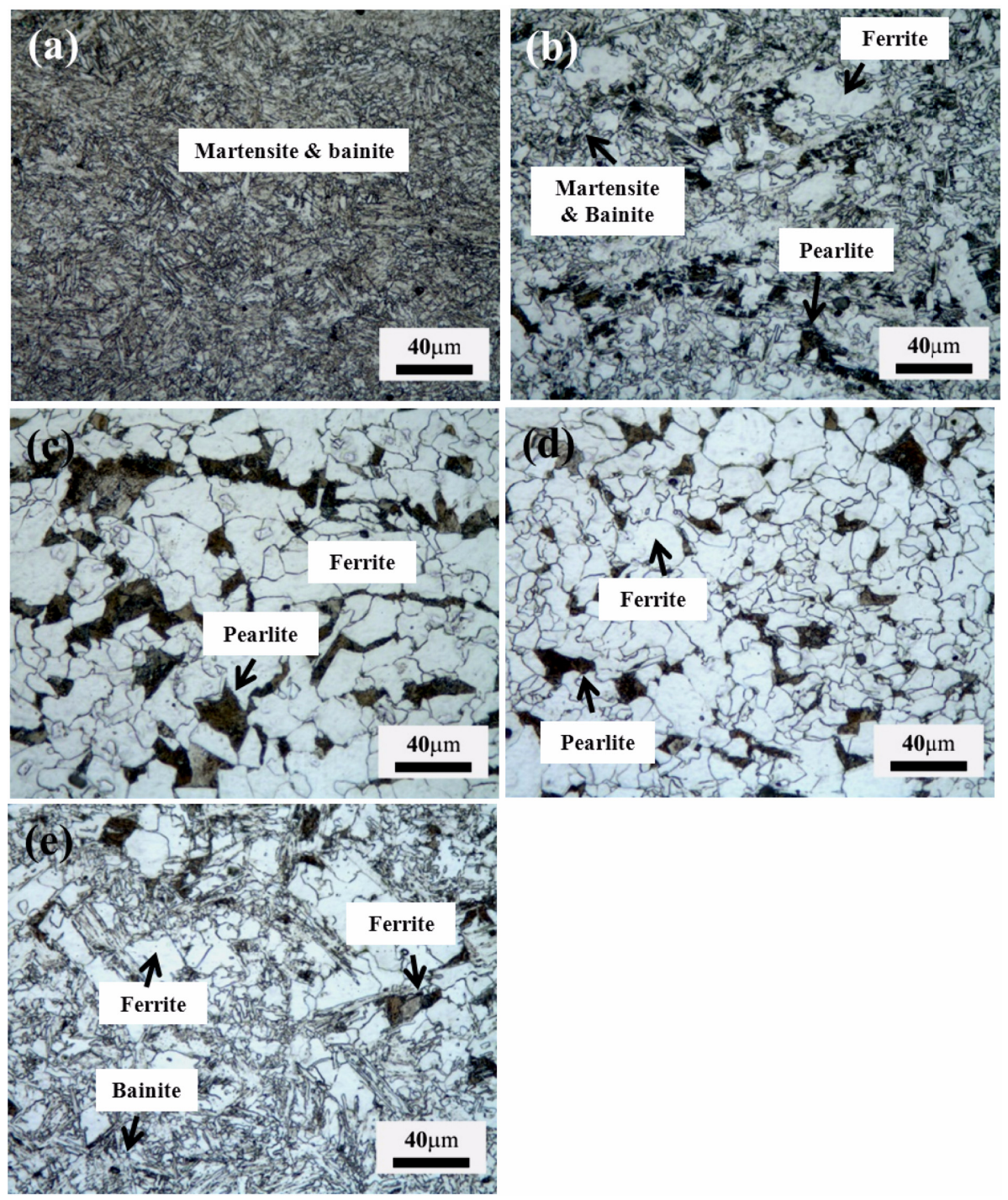

Fig. 4. Optical micrographs taken at various locations of the web part. (a) upper surface, (b) $2 \mathrm{~mm}$ from the upper surface, (c) $15 \mathrm{~mm}$ from the upper surface, (d) $27 \mathrm{~mm}$ from the upper surface, and (d) lower surface.

에 의해 저온 변태상인 마르텐사이트와 베이나이트의 생성이 억제되는 반면, 페라이트와 펄라이트의 변태 가 촉진되었기 때문이다. 이 후 경도는 $20 \mathrm{~mm}$ 두 께 지점까지 점차적으로 감소하다가, 플랜지의 내부 표면에서 페라이트 결정립 미세화에 의해 약간 증가 하였다. 이처럼, $\mathrm{H}$ 형강의 플랜지는 그 두께에 따라 마르텐사이트와 베이나이트의 경한 상에서부터 페라 이트와 펄라이트의 연한 상까지 다양한 미세조직을 가지며, 이에 따라 두께별로 $310 \mathrm{Hv}$ 에서 $180 \mathrm{Hv}$ 의 넓은 범위의 경도 값을 가짐을 알 수 있었다.
$\mathrm{H}$ 형강의 웹 부분은 그림 1(b)에서 유추할 수 있 듯이, 냉각수 분사가 직접적으로 되지 않았지만, 냉 각 공정 중에 윕의 윗 표면부에 고인 냉각수에 의 한 빠른 냉각이 이루어진다. 따라서, 웹의 상부 표면 은 그림 4(a)에서 보는 바와 같이 플랜지 외부 표면 과 유사하게 마르텐사이트와 베이나이트의 혼합조직 으로 이루어져 있다. 약 $2 \mathrm{~mm}$ 두께 지점부터 페라 이트와 펄라이트가 생성되기 시작하여 약 $28 \mathrm{~mm}$ 까 지 페라이트와 펄라이트의 이상 조직이 관찰되었다 (그림 4(b)). 웹 중심부(그림 4(c))의 펄라이트의 분 


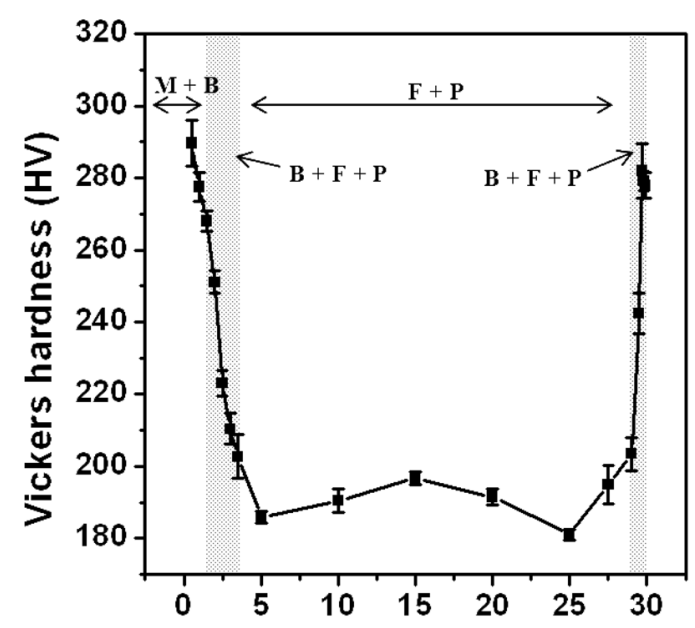

Distance from upper surface $(\mathrm{mm})$

Fig. 5. Variation in hardness with the distance from the upper surface of the web part. M, B, F, and P indicate martensite, bainite, ferrite, and pearlite, respectively.

율은 약 $20 \%$ 로 플랜지 중심부 $(15 \%)$ 보다 조금 높 았으며, 페라이트 결정립 크기 또한 약 $20 \mu \mathrm{m}$ 로 플 랜지 중심부 $(14 \mu \mathrm{m})$ 보다 약간 큰 것을 확인할 수 있었다. 이는 웹 부분의 냉각속도가 직접적인 냉각수 분사가 이루어지는 플랜지 부분의 냉각속도보다 느리 기 때문인 것으로 생각된다. 윕의 하부 표면(그림 $4(\mathrm{e})$ )은 냉각수에 의해 직접적인 냉각이 되지는 않지 만, 충분한 공랭에 의해 베이나이트의 저온 변태상이 다시 관찰되었다.

웹의 상부 표면에서부터 두께에 따른 경도 변화를 그림 5에 나타내었다. 마르텐사이트와 베이나이트의 혼합조직으로 이루어진 윕의 상부 표면는 $250 \mathrm{Hv}$ 이상의 높은 경도를 나타내었다. 그러나, 이 경도값 은 플랜지의 표면 경도 $(300 \mathrm{Hv})$ 보다 조금 낮은데, 이는 웹 부분이 플랜지 부분보다 상대적으로 느린 냉각속도로 인해 마르텐사이트 분율이 낮고 베이나이 트 분율이 높기 때문이라 생각된다. 윕의 두께가 점 차 증가함에 따라 페라이트와 펄라이트 변태가 촉진 되어 경도는 약 $5 \mathrm{~mm}$ 지점까지 급격히 감소함을 알 수 있다. 페라이트와 펄라이트의 이상조직을 갖는 $3 \sim 28 \mathrm{~mm}$ 지점에서는 $180 \mathrm{Hv}$ 와 $200 \mathrm{Hv}$ 사이의 비 교적 낮은 경도 값이 유지되는 반면, 베이나이트가 다시 관찰되는 웹의 하부 표면 $(29 \mathrm{~mm})$ 에서는 경도 값이 급격히 증가하였다.
$\mathrm{H}$ 형강의 부위별 석출물의 분포는 플랜지와 웹의 중심부에서 탄소 추출 복제막을 제작하여 $\mathrm{TEM}$ 을 사용하여 관찰하였다. TEM을 이용하여 플랜지 중심 부의 석출물 분포를 조사한 결과, 그림 $6(\mathrm{a})$ 에 나타 낸 바와 같이 크기에 따라서 약 $30 \mathrm{~nm}$ 내외의 석 출물과 $10 \sim 20 \mathrm{~nm}$ 의 석출물, 그리고 $10 \mathrm{~nm}$ 이하의 미세한 석출물로 분류할 수 있었다. $\mathrm{EDXS}$ 를 이용 하여 석출물의 화학조성을 분석해 본 결과, 크기가 비교적 큰 $30 \mathrm{~nm}$ 내외의 석출물들은 $\mathrm{V}$ 과 $\mathrm{Nb}$ 의 원 자비가 약 $3: 7$ 인 $\mathrm{Nb}$-rich $(\mathrm{Nb}, \mathrm{V})(\mathrm{C}, \mathrm{N})$ 인 반면(그림 6(c)), $10 \sim 20 \mathrm{~nm}$ 의 석출물과 $10 \mathrm{~nm}$ 이하의 미세한 석출물들은 $\mathrm{V}$ 와 $\mathrm{Nb}$ 의 원자비가 약 $7: 3$ 인 $\mathrm{V}$-rich $(\mathrm{V}, \mathrm{Nb})(\mathrm{C}, \mathrm{N})$ 임을 확인할 수 있었다(Fig. 6(d)). 웹의 중심부(그림 6(b)) 또한 플랜지와 마찬가지로 약 $30 \sim 50 \mathrm{~nm}$ 의 크기가 비교적 큰 $\mathrm{Nb}-\mathrm{rich}(\mathrm{Nb}, \mathrm{V})(\mathrm{C}$, $\mathrm{N}), 10 \sim 20 \mathrm{~nm}$ 의 중간 크기의 V-rich $(\mathrm{V}, \mathrm{Nb})(\mathrm{C}, \mathrm{N})$, 그리고 $10 \mathrm{~nm}$ 이하의 미세한 V-rich $(\mathrm{V}, \mathrm{Nb})(\mathrm{C}, \mathrm{N})$ 를 관찰할 수 있었다[13].

$\mathrm{V}$ 과 $\mathrm{Nb}$ 이 복합 첨가된 미량 합금강에서 형성된 복합 탄질화물은 약 $900^{\circ} \mathrm{C}$ 이상의 고온에서는 $\mathrm{Nb}$ rich $(\mathrm{Nb}, \mathrm{V})(\mathrm{C}, \mathrm{N})$ 이 안정한 반면, 그 이하의 저온에 서는 V-rich $(\mathrm{V}, \mathrm{Nb})(\mathrm{C}, \mathrm{N})$ 이 안정하다고 알려져 있다 [11-13]. 따라서, 플랜지와 웹의 중심부에서 관찰되는 약 $30 \mathrm{~nm}$ 내외의 $\mathrm{Nb}$-rich $(\mathrm{Nb}, \mathrm{V})(\mathrm{C}, \mathrm{N})$ 은 고온의 오스테나이트에서, $10 \sim 20 \mathrm{~nm}$ 의 V-rich $(\mathrm{V}, \mathrm{Nb})(\mathrm{C}, \mathrm{N})$ 은 약 $900^{\circ} \mathrm{C}$ 이하의 비교적 저온의 오스테나이트에 서 다단 열간압연 시 생성된 것으로 생각된다. $10 \mathrm{~nm}$ 이하의 미세한 석출물들은 다단 열간압연 후 가속냉각 중에 생성되었다고 생각된다.

플랜지와 웹의 중심부에서 관찰되는 석출물의 크기 에 따른 분포를 그림 6(e)에 나타내었다. 플랜지와 웹에서 관찰되는 석출물은 대부분 $20 \mathrm{~nm}$ 이하의 Vrich 석출물이고, $30 \mathrm{~nm}$ 이상의 $\mathrm{Nb}$-rich 석출물의 빈도는 매우 적었다. 플랜지 부분의 경우 윕 부분보 다 $10 \mathrm{~nm}$ 이하의 미세한 석출물의 비율은 높은 반 면, $10 \sim 20 \mathrm{~nm}$ 의 석출물 의 비율은 낮았는데, 이는 플랜지 부분에서는 가속냉각으로 인해 V-rich 석출물 들이 성장할 시간이 적었던 반면, 웹 부분에서는 가 속냉각이 효과적으로 이루어지지 않아 V-rich 석출물 들이 성장할 충분한 온도와 시간이 주어졌기 때문으 로 생각된다. 이처럼, 플랜지 부분의 비교적 작은 크 

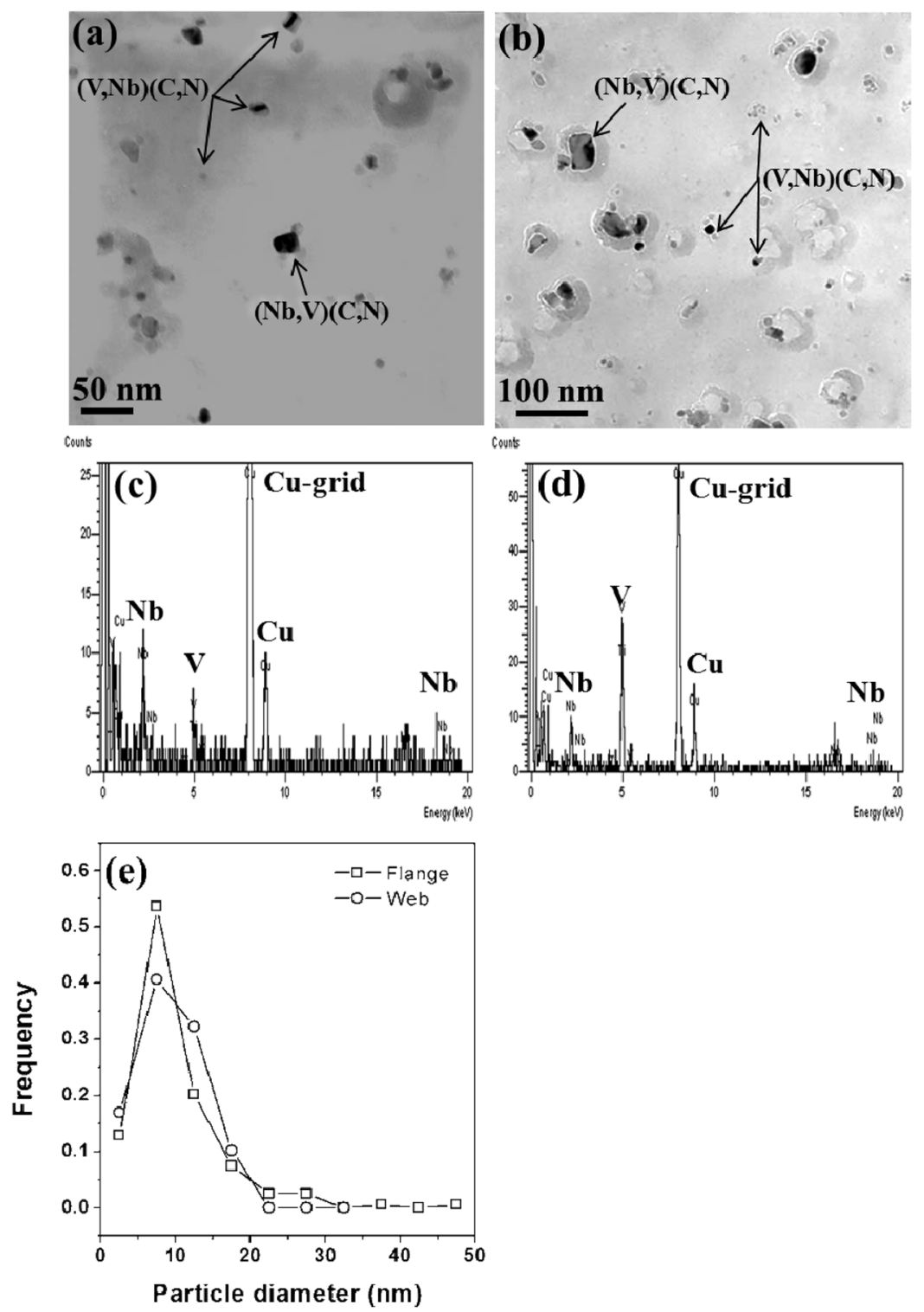

Fig. 6. Carbon extraction replicas showing precipitates in the middle parts of (a) flange and (b) web of H-sectional steel [13]. EDSX spectra of (c) Nb-rich $(\mathrm{Nb}, \mathrm{V})(\mathrm{C}, \mathrm{N})$ and $(\mathrm{d})$ V-rich $(\mathrm{V}, \mathrm{Nb})(\mathrm{C}, \mathrm{N})$ precipitates at the flange part and (e) distributions of precipitate sizes in both flange and web parts.

기의 석출물 분포 또한 플랜지의 강도를 높이는데 기인했을 것이라 생각된다. 상기의 미세조직, 석출물 관찰과 경도 측정 결과를 통해 표 1 의 플랜지의 항 복강도와 인장강도가 웹보다 높은 이유는 플랜지 부 분이 가속냉각에 의해 저온 변태조직의 분율이 높을 뿐 아니라, 석출물의 크기 또한 웹 부분에 비해 작 기 때문인 것으로 생각된다.

\section{4. 결 론}

본 연구에서는 가속냉각으로 제조된 고강도 대형 $\mathrm{H}$ 형강의 미세조직, 석출물 분포, 그리고 경도 값을 각 부위별, 두께별로 조사하였다. 냉각수 분사에 의 해 직접 수냉된 플랜지의 외부 표면은 냉각속도가 빨라서 마르텐사이트와 베이나이트의 이상 조직으로 
구성되어 있었고, $300 \mathrm{Hv}$ 이상의 높은 경도 값을 나타내었다. 플랜지 내부로 갈수록 페라이트와 펄라 이트의 분율이 점차 증가하고, 이에 따라 경도는 감 소하였으나, 페라이트의 미세화가 관찰되는 플랜지의 내부 표면에서 경도가 소폭 증가하였다. 형강의 웹 부분에서는 저온 변태상이 관찰되는 상하부 표면에서 경도 값이 약 $290 \mathrm{Hv}$ 로 높았으며, 내부로 갈수록 경도 값은 점차 감소하였다. 플랜지와 웹 부분 모두 $30 \sim 50 \mathrm{~nm}$ 의 Nb-rich 석출물과 $20 \mathrm{~nm}$ 이하의 Vrich 석출물이 관찰되었으나, 플랜지의 석출물의 크기 가 웹보다 상대적으로 작았다. 플랜지의 항복강도와 인장강도가 웹보다 높은 이유는 플랜지 부분이 냉각 수 분사를 직접 받아 빠른 냉각속도로 냉각이 되었 기 때문에 저온 변태조직의 분율이 높을 뿐 아니라, 석출물의 크기 또한 웹 부분에 비해 작기 때문인 것으로 생각된다.

\section{감사의 글}

본 연구는 지식경제부의 차세대 초대형 구조물용 강재 개발 사업 중 초고장력 $\mathrm{H}$ 형강 및 철근 기술 개발 과제의 일환으로 수행되었으며, 이에 감사 드립 니다.

\section{References}

1. S. S. Campos, E. V. Morales and H. J. Kestenbach : Metall. Mater. Trans. A 32A (2001) 1245.

2. R. D. K. Misra, K. K. Tenneti, G. C. Weatherly and G. Tither : Metall. Mater. Trans. A 34 A (2003) 2341.

3. B. Dutta and C. M. Sellars : Mater. Sci. Technol. 2 (1985) 146.

4. M. Gómez, L. Rancel and S. Medina : Met. Mater. Int. 15 (2009) 689.

5. E. Valdes and C. M. Sellars : Mater. Sci. Technol. 7 (1991) 622.

6. L. N. Pussegoda, S. Yue and J. J. Jonas : Mater. Sci. Technol. 7 (1991) 129.

7. O. Kwon and A. J. DeArdo : Acta Mater. 39 (1991) 529.

8. Y. -S. Park, C. -S. Choi and I. -S. Chung : J. Korean Soc. Heat Treat. 14 (2001) 267.

9. K. -H. Kim, K. -W. Kwon and I. -S. Yoo : Proc. of the 9th Conf. on Mech. Behaviors of Materials, Kwangyang, Korea, 189.

10. J. -W. Lee, H. -C. Lee, Y. -J. Lee, Y. -T. Seo, Y. -G. Lee, D. -H. Bae, S. -W. Lee and Y. -J. Oh : Trends in Met. \& Mater. Eng. 19 (2006) 11.

11. K. A. Taylor: Scripta Mater. 32 (1995) 7.

12. A. Pandit, A. Murugaiyan, A. S. Podder, A. Haldar, D. Bhattacharjee, S. Chandra and R. K. Ray : Scripta Mater. 53 (2005) 1309.

13. Y. -S. Ha, J. -G. Jung and Y. -K. Lee : Kor. J. Met. Mater. 49 (2011) 917. 